\title{
التأصيل الإسلامي لمفهوم القيم
}

فتحي حسن ملكاوي

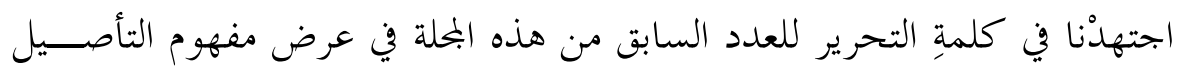

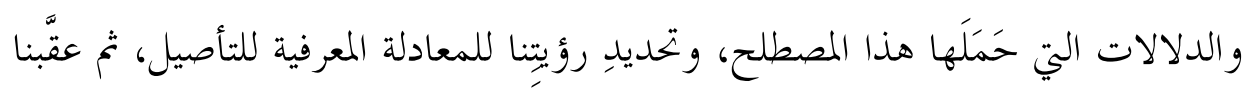

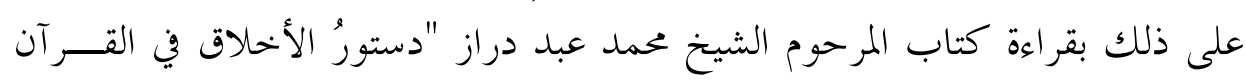

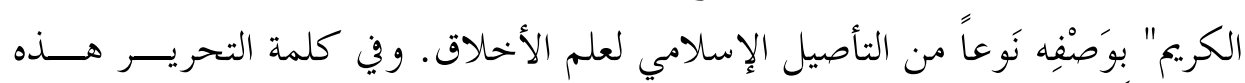

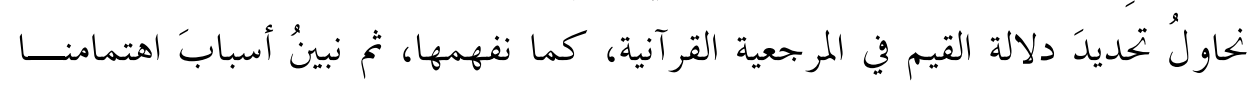
بالتأصيل الإسلامي لمفهوم القيم.

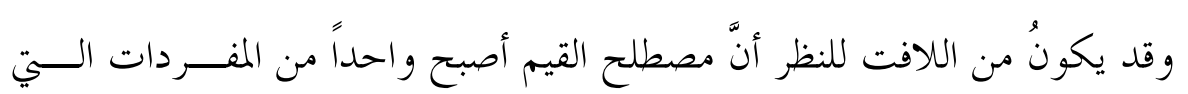

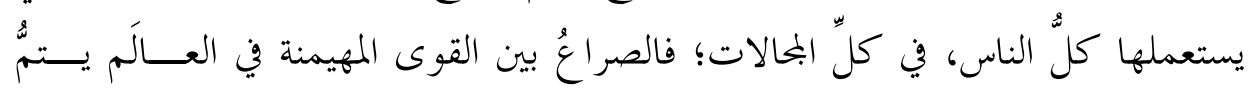

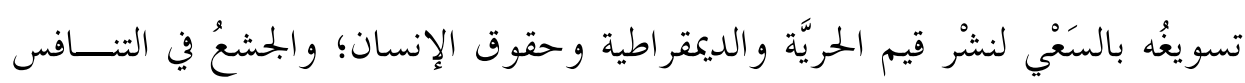

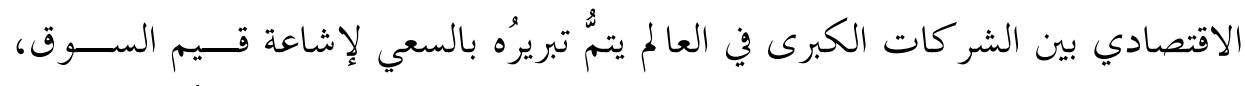

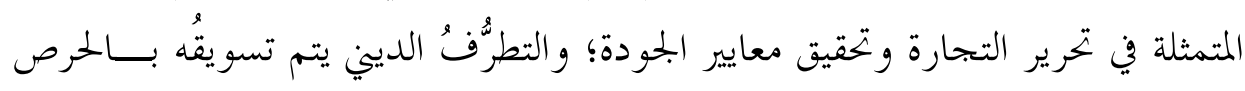

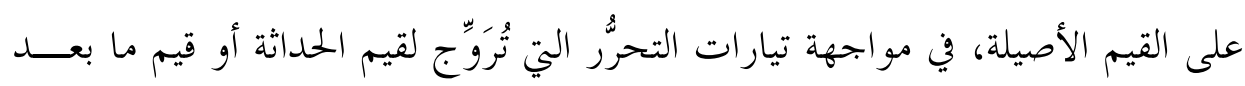
الحماثة، إلخ. الخم الاصني

لذلك لا عجبَ أن أصبحَ موضوعُ القيم مادةً للبحث والدراسة، يستقطب اهتمامَ

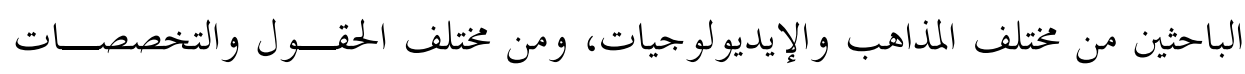

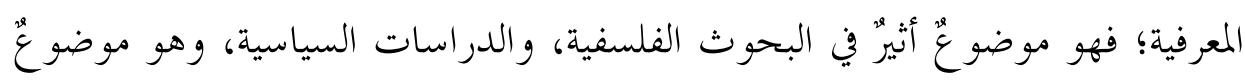

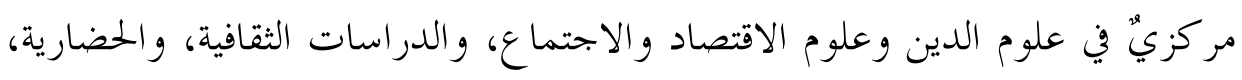


إلخ، هذا فضلاً عن أنَّ موضوعَ القيم يتعلق بالفطرة الإنسانية، ويضربُ بعيداً في عمق

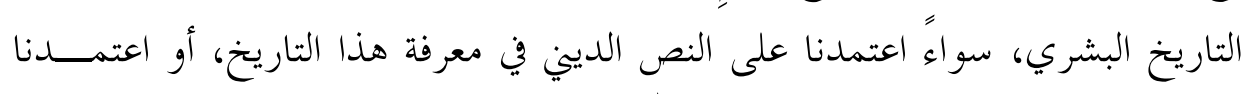

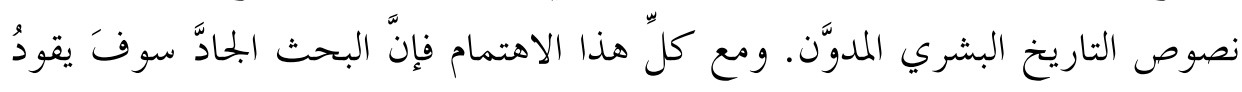

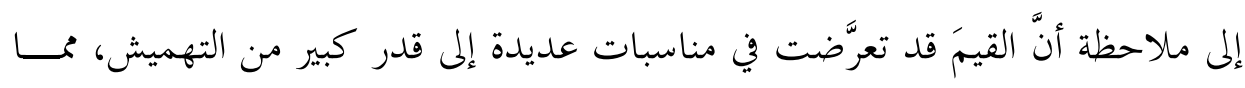

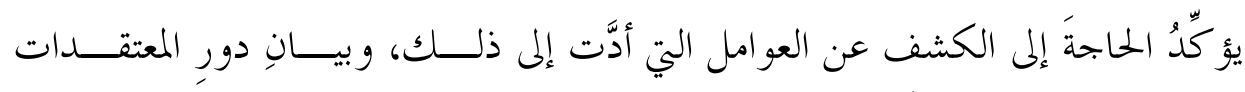

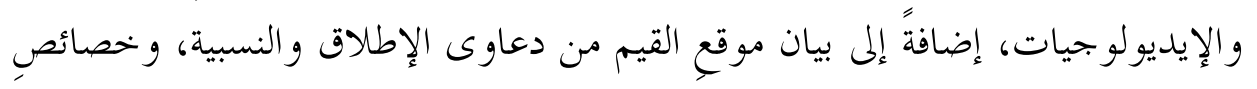
التغيٌّر و الثبات.

\section{مفهوم القيم}

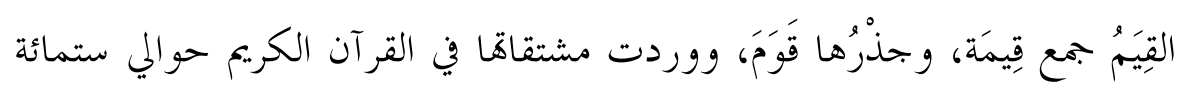

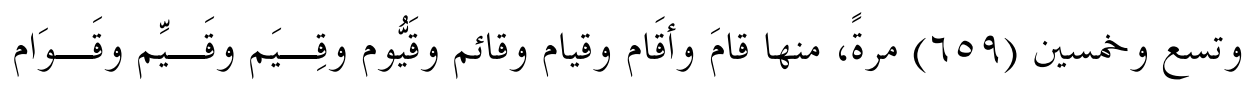

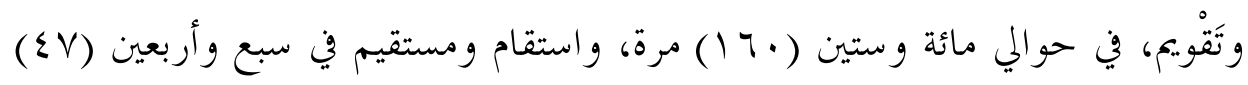

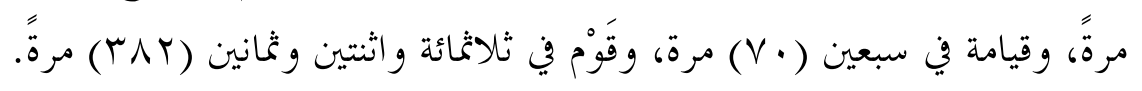

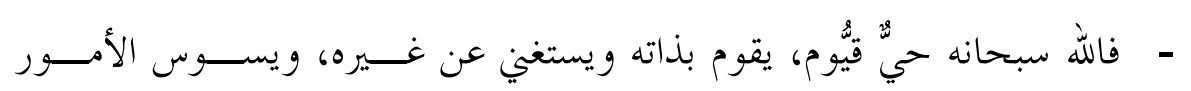

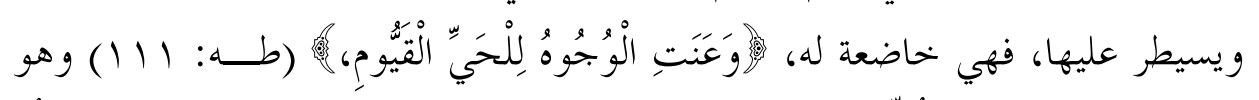

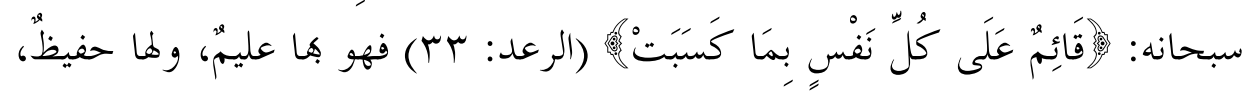
وعليها رقيب.

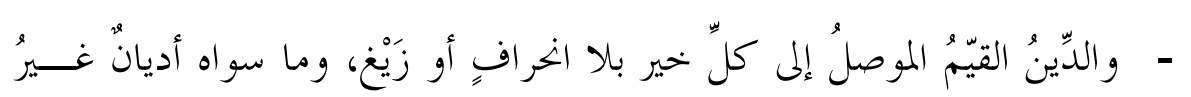

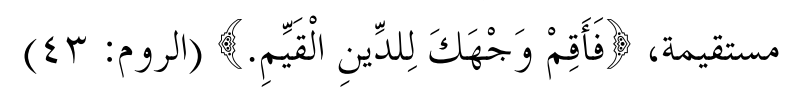

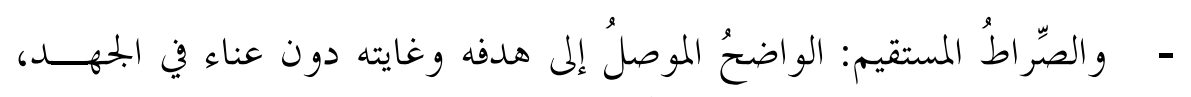

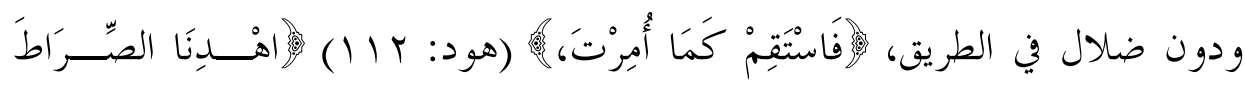
الْمُسْتَقِيَمَ. 


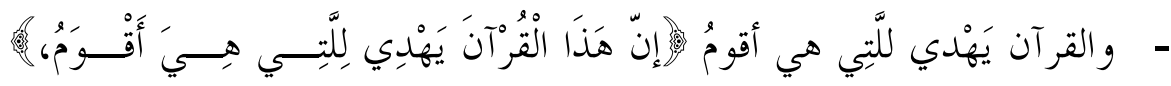

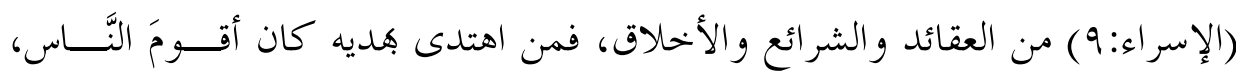

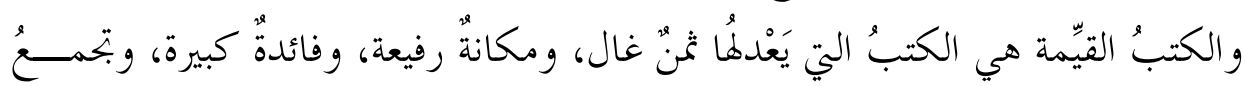

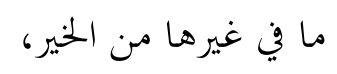

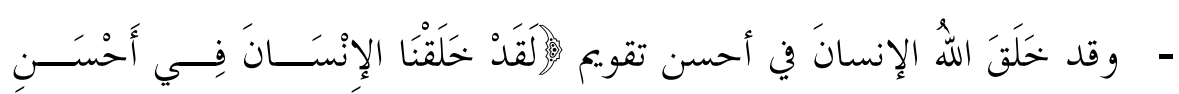

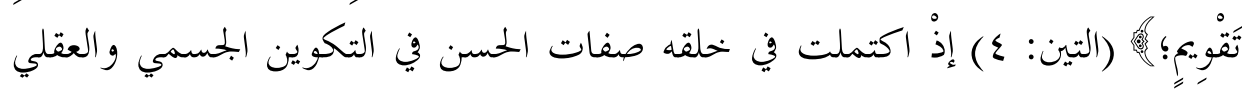

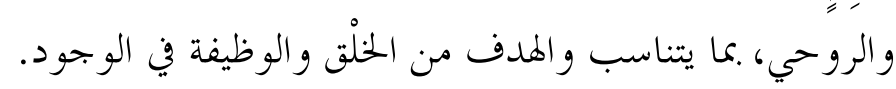

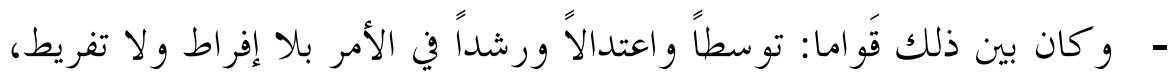

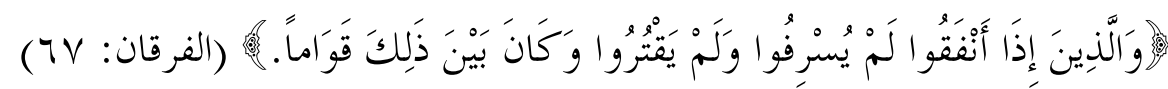

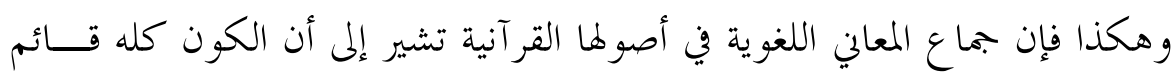

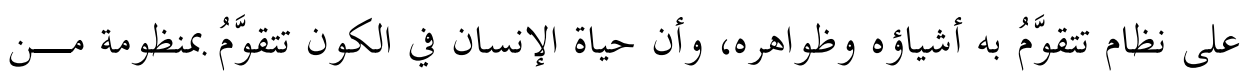

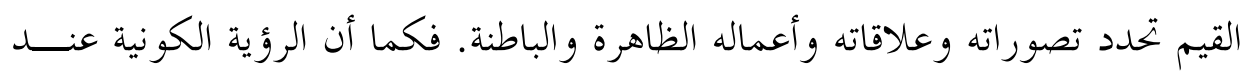

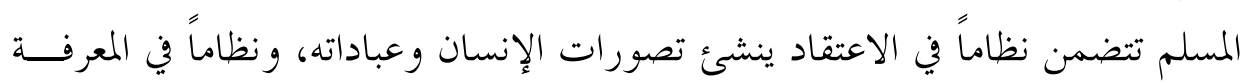

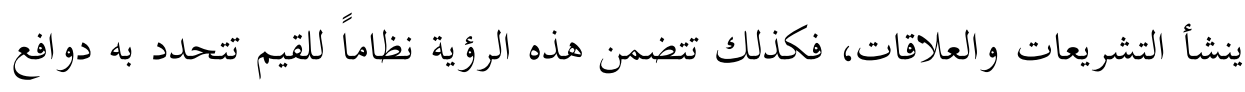
السلوك و العمل. نظام الإسلام= نظام الاعتقاد + نظام المعرفة + نظام القيم.

ومع أنَّ هذه الرؤية هي رؤية أصيلة ذاتُ مر جعية قرآنية، فإنَّ بعض الفلاسفة قـــــ

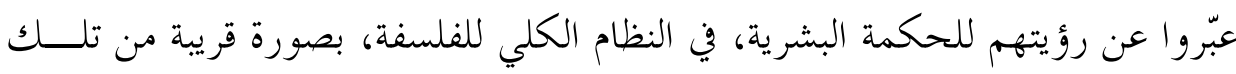

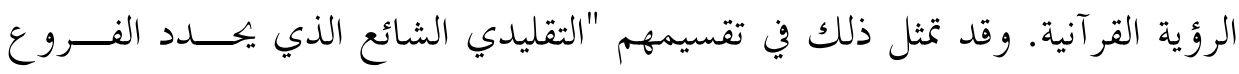

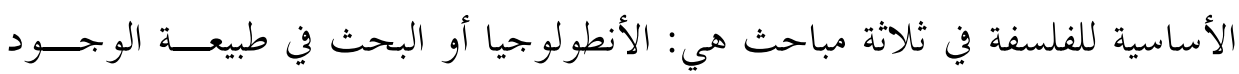


وحقيقته، والإبستمولوجيا أو نظرية المعرفة، والأكسيولوجيا وهي البحث في ماهيــة

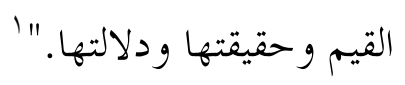

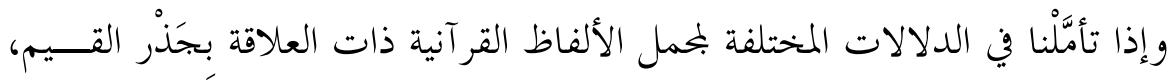

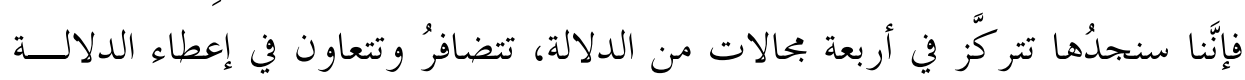

$$
\text { الكليّة للقيمة والقيم في الاصطلاح القرآين، وهذه البحالات الأربعة هي: }
$$

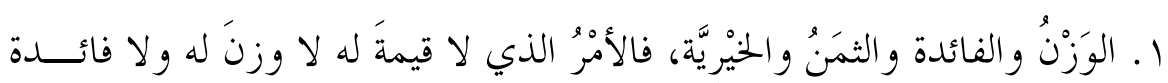

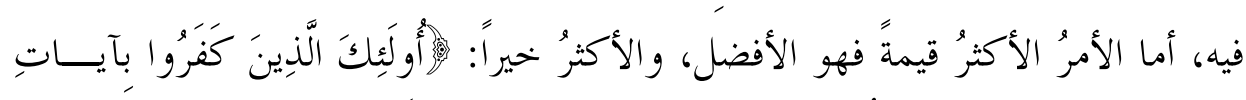

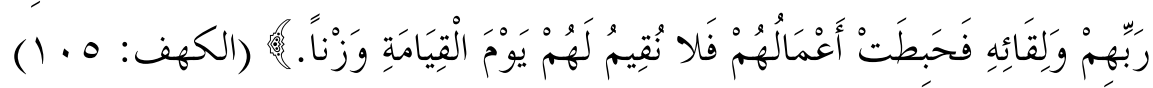

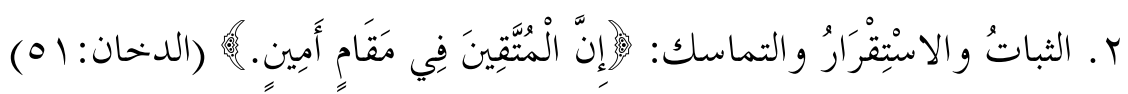

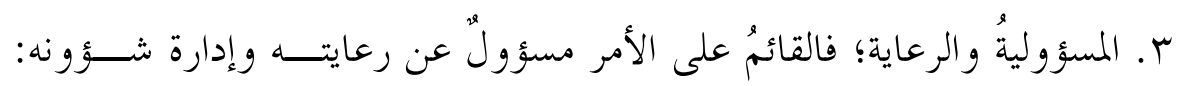

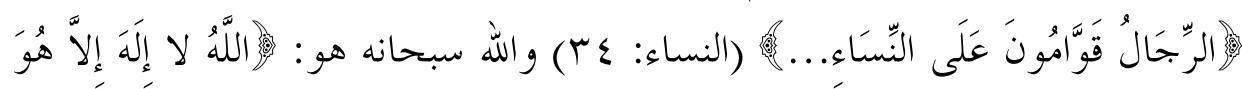

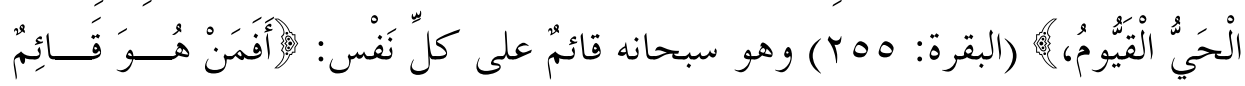

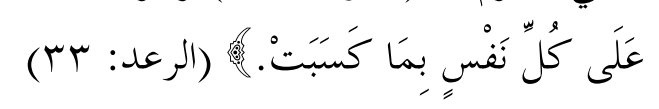

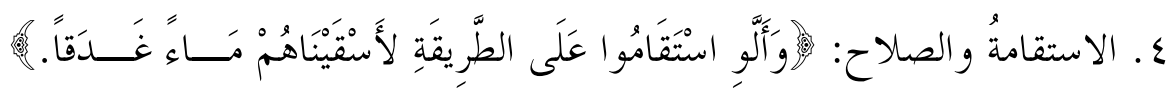

إنَّ مراجعةَ التراث الإسلامي تكشفُ عن غياب مصطلح "القيم" بالدلالة المعاصرة

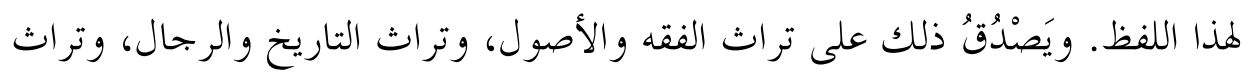

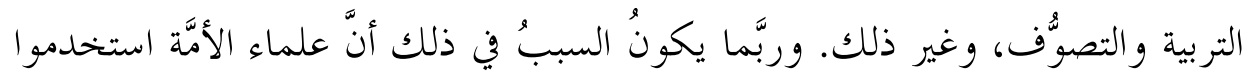

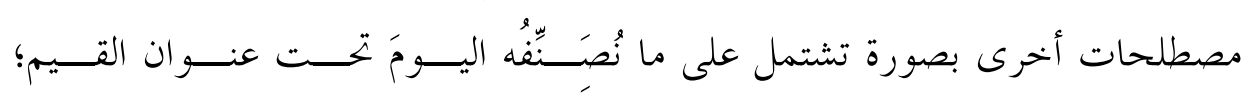

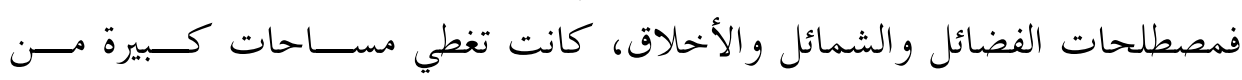


خصائص السلوك البشري. أما دوافع هذا السلوك فكانت ترتبط بأركسـان الإســالام

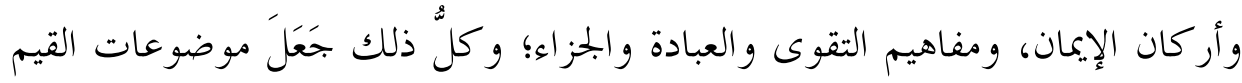

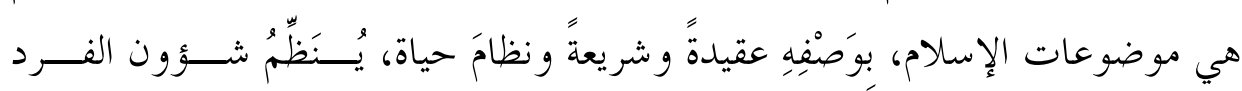
و البحتمع، وتتكامل فيه متطلباتُ العمل للدنيا والآخرة.

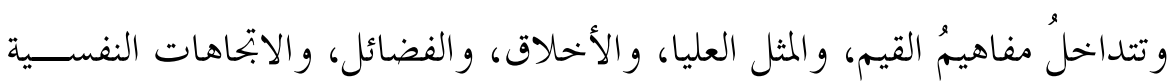

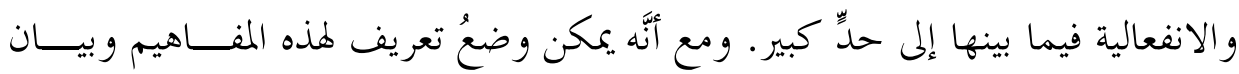

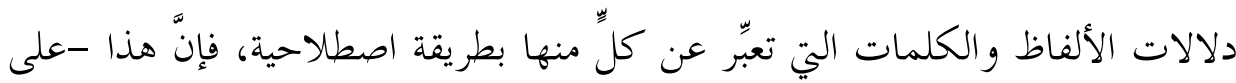

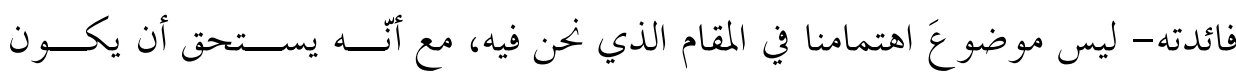

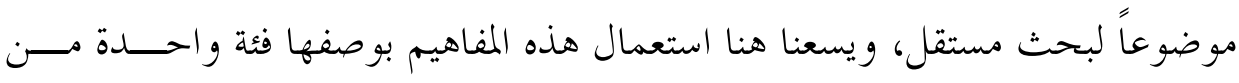

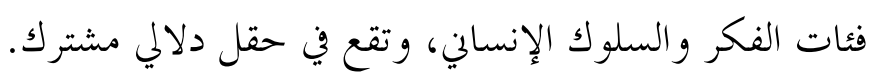

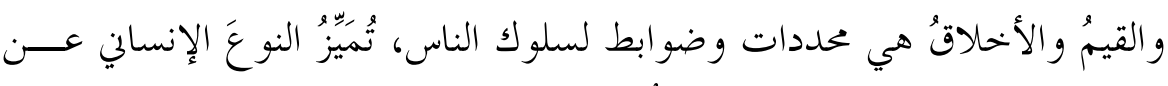

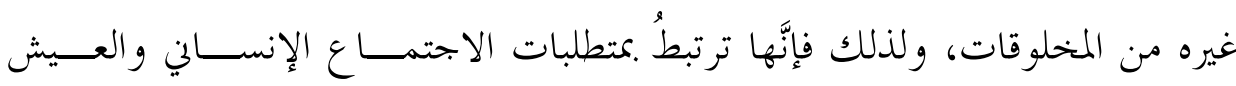

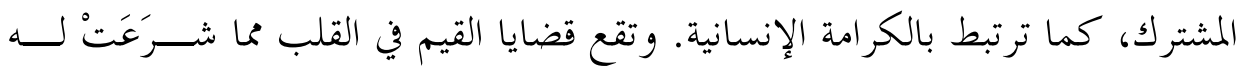

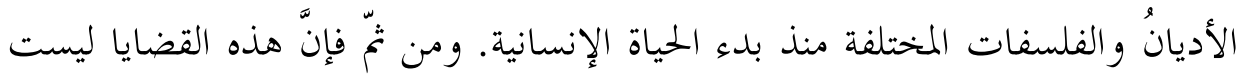

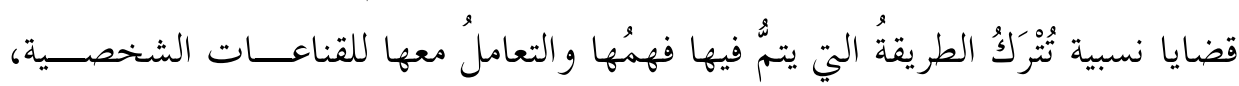

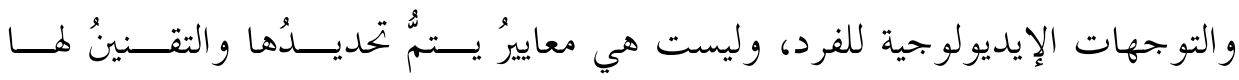

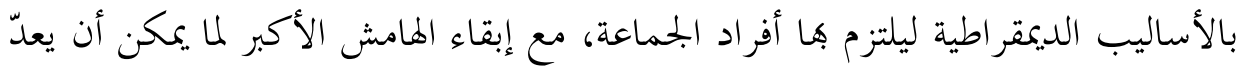

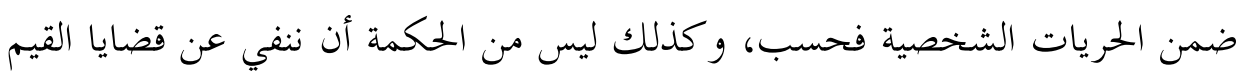

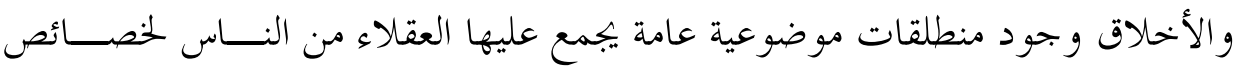
فيها في حد ذاها. والقيمُ و الأخلاق -في هذا السياق- لا تقتصر على ما كان معروفاً مــن قضــايا

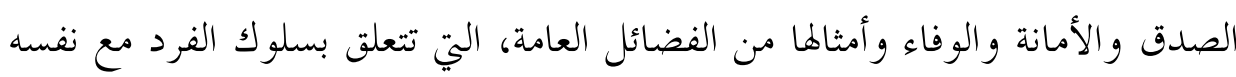

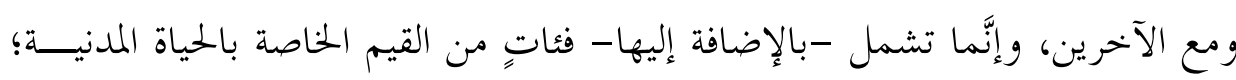


من مسؤولية اجتماعية، واحترام الآخرين، وقيم الولاء و الانتماء العامـــة في دوائــــه

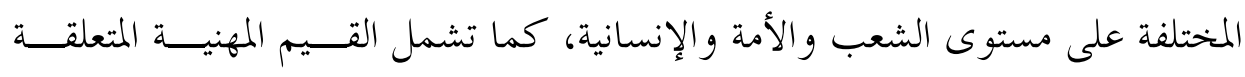

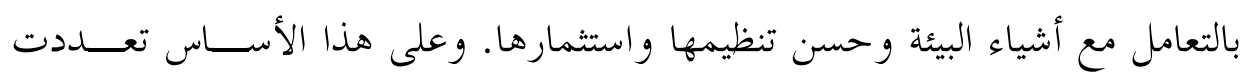

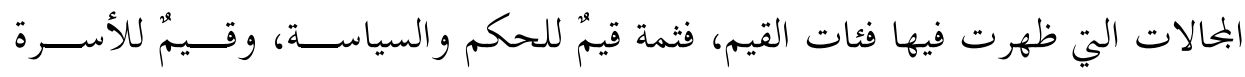

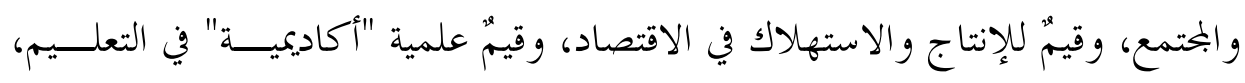

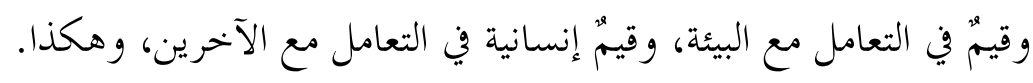

وعند تحليل موقع القيم في الحياة العامَّة، نلاحظٌ أنَّ قضايا القيم و الأخلاق في كثير

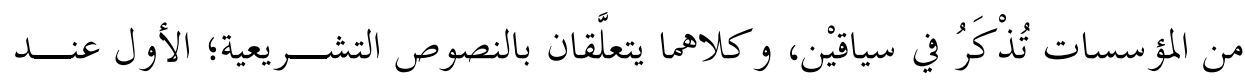
تحديد رؤية المؤسسة ورسالتها وأهدافها العامة، وترد في نصوص عامة إنشائية، و الثاني

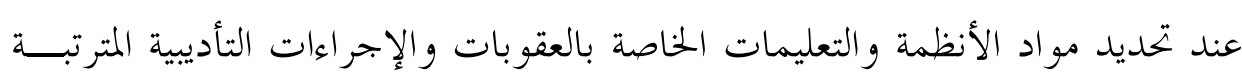

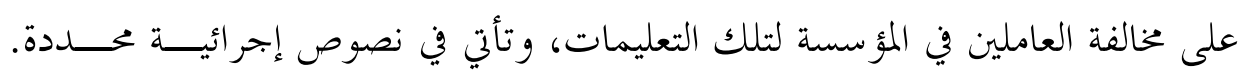
ونحن نرى ضرورةَ القيام بتحويل جذري في طبيعة الاهتمام بالبعد القيمي والأخلاقي،

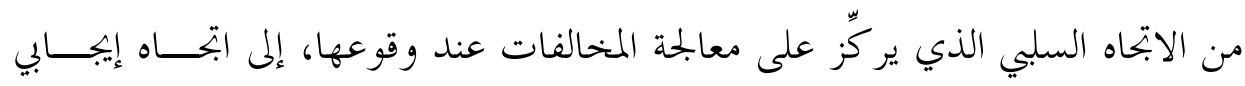

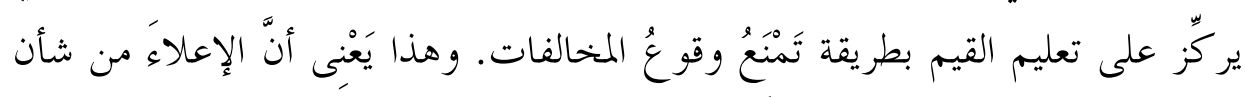

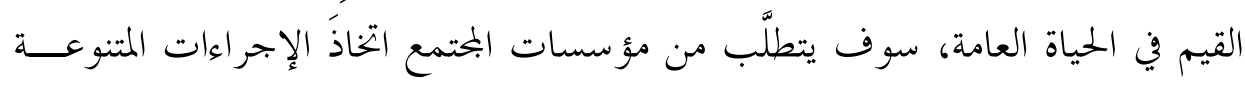

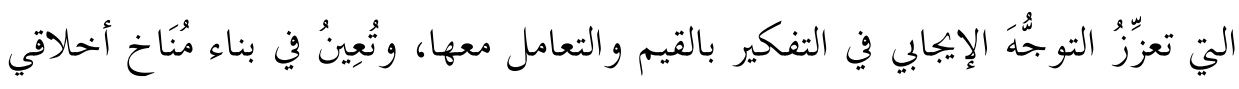

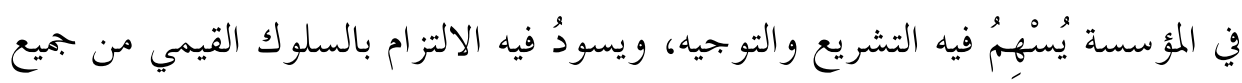

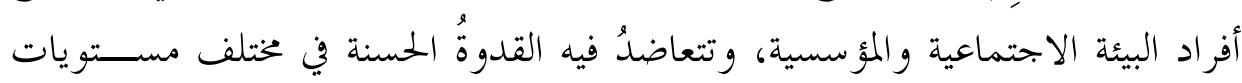

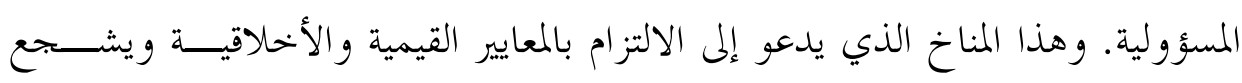

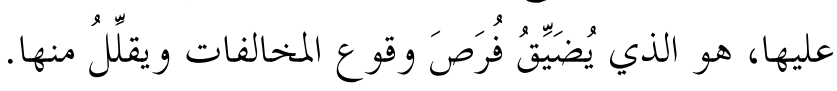

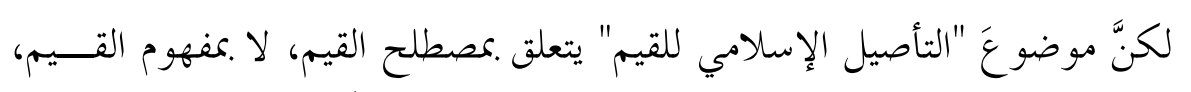

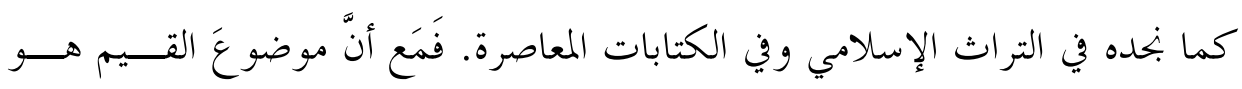

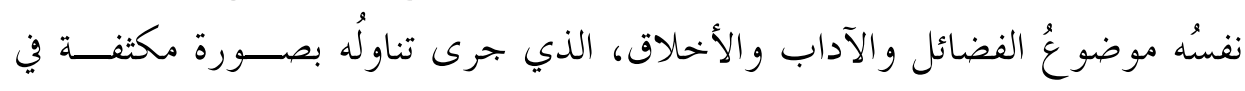


التراث الإسلامي، فإنَّ مصطلحَ القيم لم يكنْ مستعملاً في أدبيات هذا التراث، رغــــم

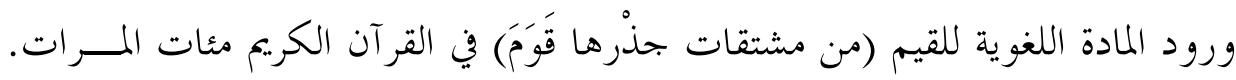

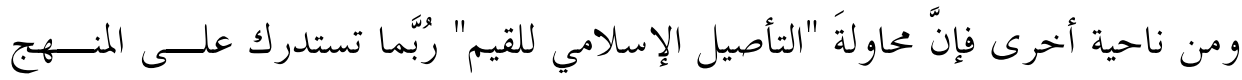

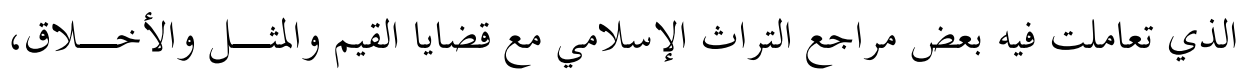

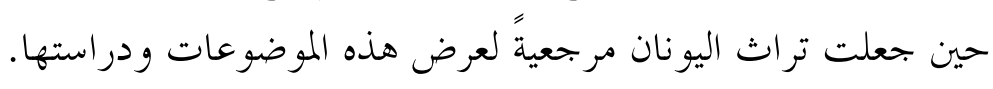

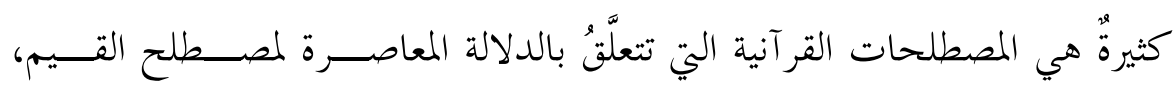

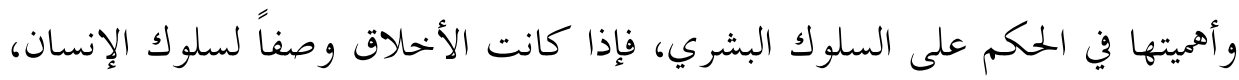

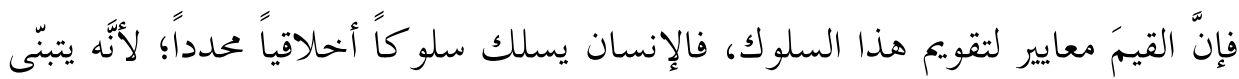

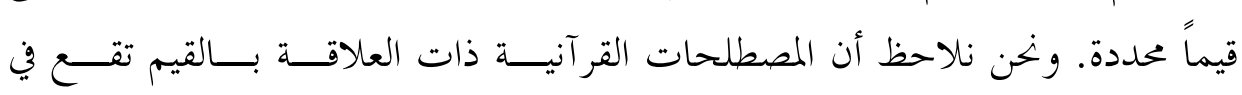
مستويات مختلفة في العموم والخصوص؛ إذ يمكن تصنيف القيم في فئات حسب معايير متعددة:

- فالحقُّ، و العدل، و الخيرُ، و الإحسانُ، و التقوى هي قيمّ عليا حاكمة رئيسـية،

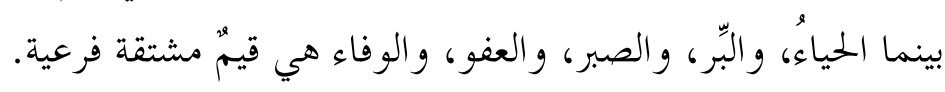

- ـ و العَدل، و الشورى، و الحريَّة، قيمّ في البناء السياسي للأمَّة؛ و التكافل، و الكرم،

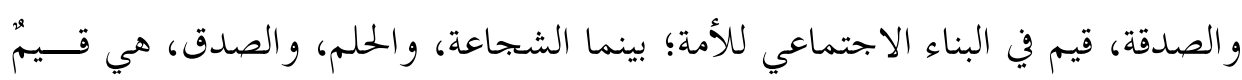
في التز كية النفسية للأفراد.

- - وقد يكونُ التصنيف على أساس التمييز بين قيم الأمر وقيم النهي. - - وقد يكون التصنيف على أساس القيم الواجبة والقيم المندوبة. - ـ وقد تكون "مقاصدُ الشرع" الخمسة نظاماً مناسباً لتصنيف القيم، تندرج تحت كل منها قيم فرعية منبثقة عنها. - ـ والإسلام هو "الدين القيِّم" و"دين القيِّمة"، وقد تكرر ذلك في القرآن الكريم

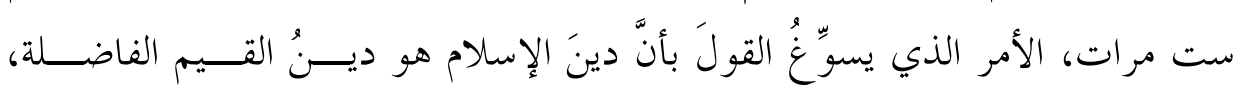


و الثابتة. ومن ثَمَّ فإنَّ نظامَ القيم في الإسلام هو نظامُ الإسلام بصورته الكلية العامـــة: عقيدة، وعبادة، و شريعة، وأخلاقاً. -...

لكنَّ أيَّ تصنيف للقيم لا يُلْغِي حقيقة التداخل و الترابط بين المعاني والـــلالات

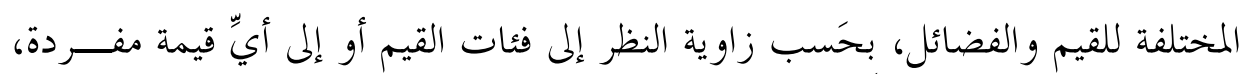

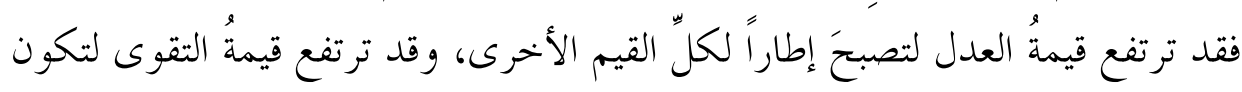

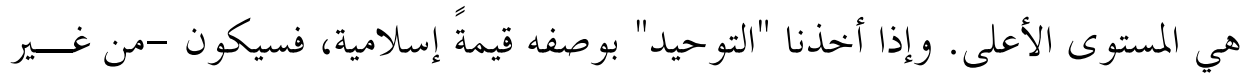
شك- هو القيمة العليا.

أمَّا في الكتابات المعاصرة، فإنَّ مصطلح القيم يظهر بطرق عديدة، معظمُها يعكس

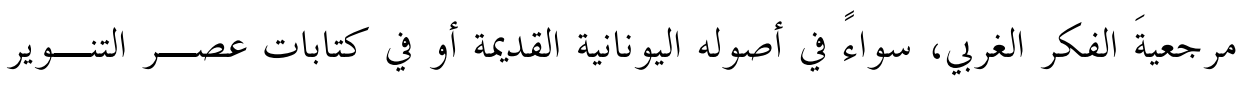

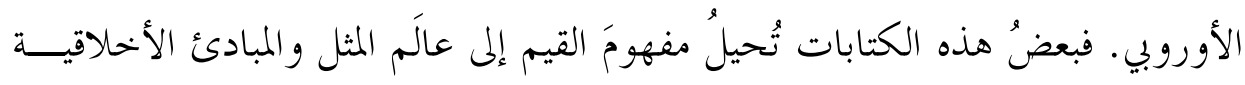

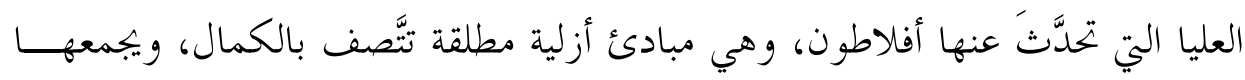

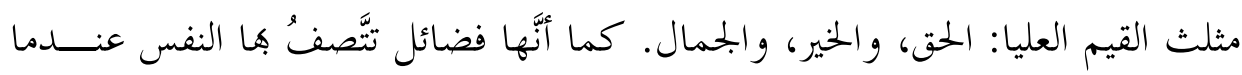

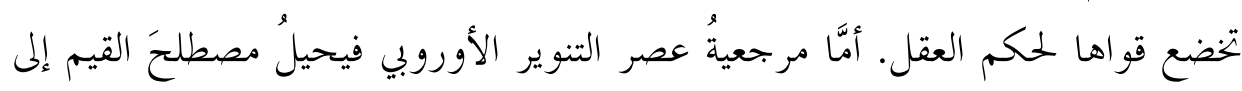

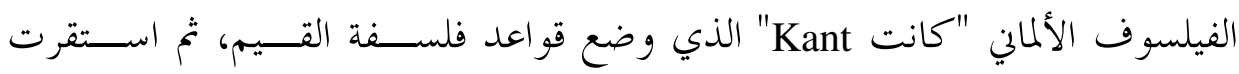
الموسوعات و المعاجم الفلسفية على عدّ "علم القيم Axiology" فرعاً مـــن الفلســــة.

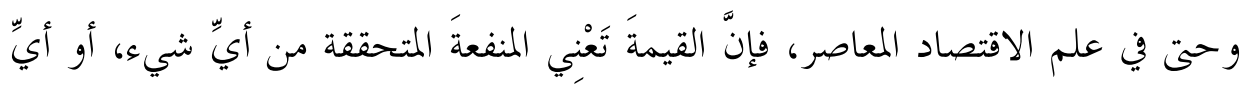

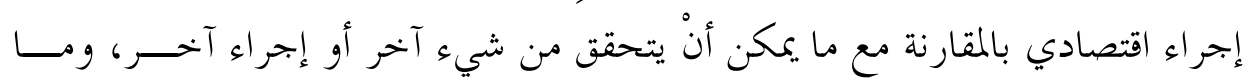

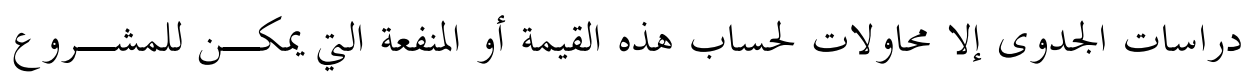
المقتر ح أن يجققها.

إنَّ نظامَ الاعتقاد في الإسلام هو الأساسُ لنظام القيم، فإذا كانــتـ العقيـــدة في الإسلام تقرِّر أن الله سبحانه قد خلق الإنسان ليكون خليفةً في الأرض، فإنَّ نظام القيم 
هو بحموعة المبادئ و المعايير التي تستهدف ضبط السلوك البشري وتوجيهه؛ لتحقيــق

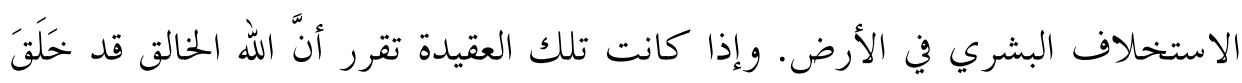

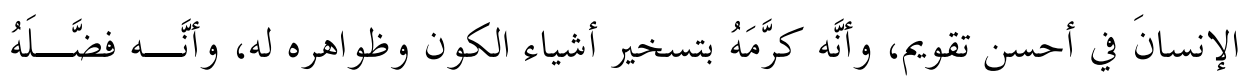

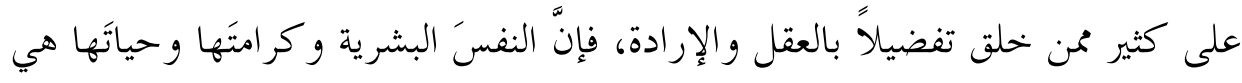

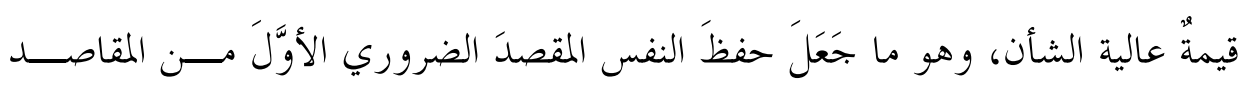

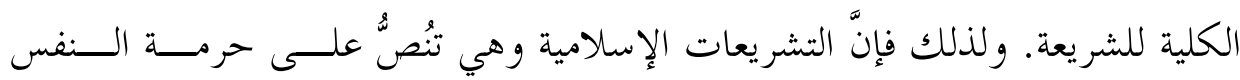
الإنسانية وصيانتها من أي ظلم أو اعتداء، إنَّما تؤ كد البعد القيمي والأخلاقي للشريعة

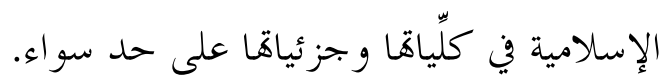

و القيم والأخلاق في التفكير الإسلامي أمورٌ شرعية معقولة؛ فعندما نقول: الحَسَنُ

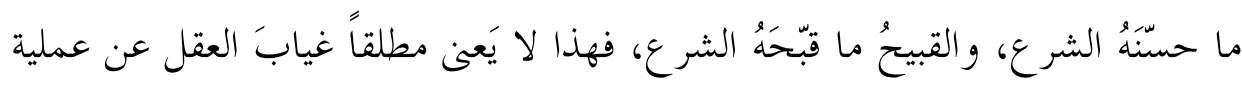

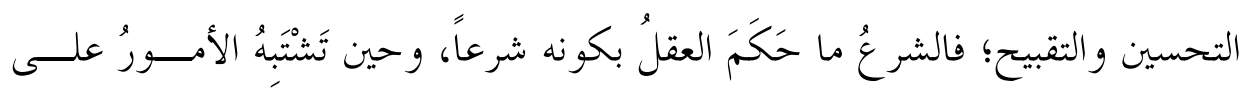

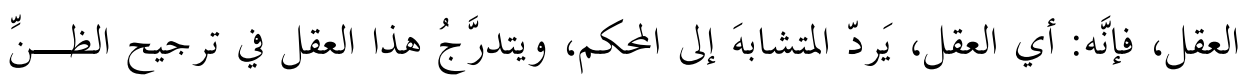
درجةً درجةً في ابتحاه اليقين.

ومع أنَّ الفردَ الإنساني يتشرَّبُ منظومةَ القيم من البيئة الاجتماعية التي ينشأ فيها،

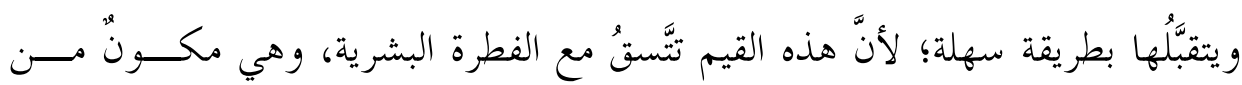

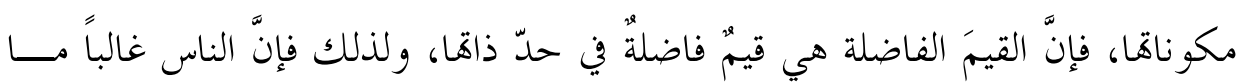

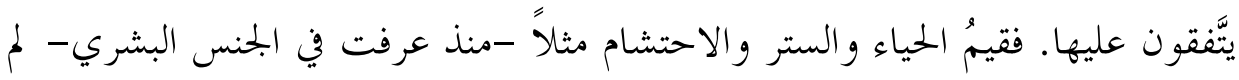

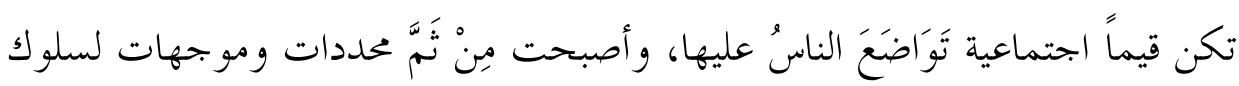

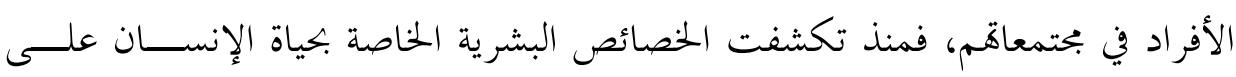

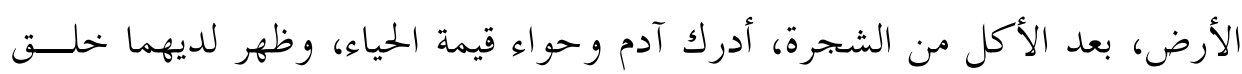

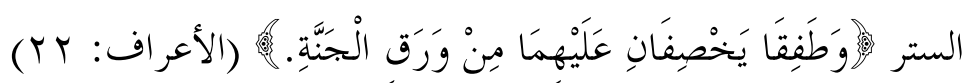


ثمَ إنَّ الإنسان لا يعيش إلا في بحتمع، فالتجمُّعُ الإنساني فطرةٌ بشرية؛ وليس ثَدَّـــة تجمع دون نظام ومعايير وقيم يقبل هها المحموع و يرتضوها. وهذه القيم لا بد أن تتصف

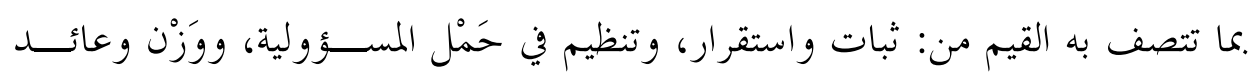

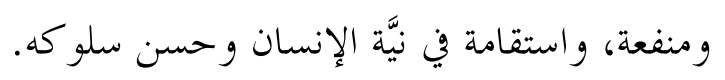

وهكذا ينشأ الإنسان منذ و لادته على القيم الفاضلة التي يتشـــرَّها الفــــدُ مـــن

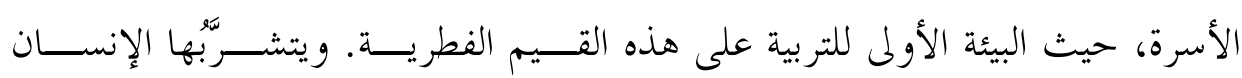

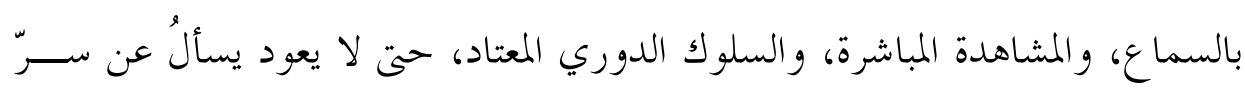

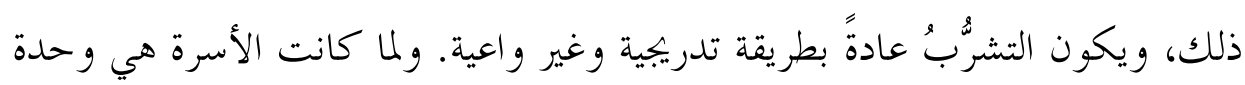

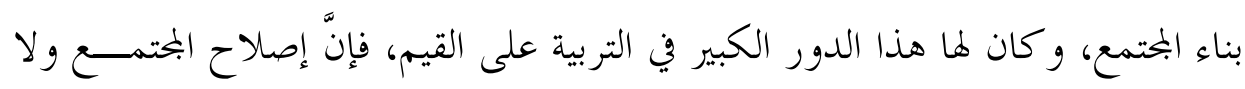
سيّما في بحال القيم والأخحلاق، إنَّمَا يبدأ في الأسرة.

فالأسرةٌ في التفكير الإسالامي هي مستودوعُ القيم؛ فللمرأة في الأســـرة أنوثتـــها، وأنوثة المرأة قيمةٌ جمالية ذاتُ أسرار عميقة، و كذلك رجولة الرجل في في الأسرة، فالمرأة لا تكتمل شخصيتُها البشرية إلا بالرجل، و كذلك الرجل، لا تكتمل شخصيتُه البشرية

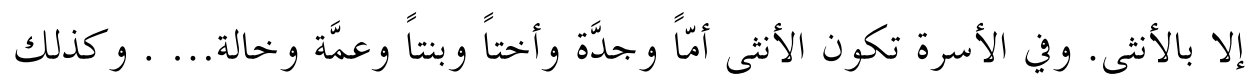

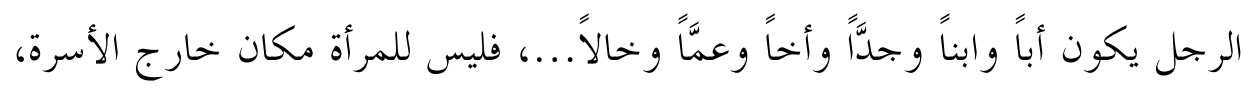
وليس للرجل مكان خحارج الأسرة أيضاً.

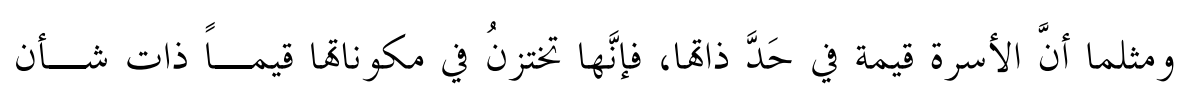

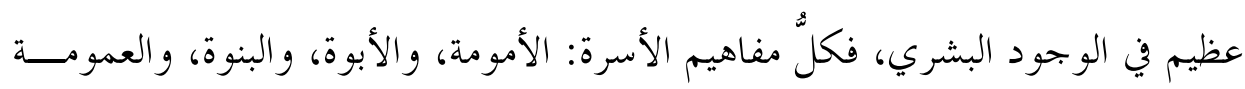

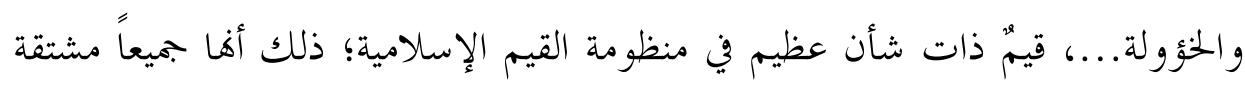

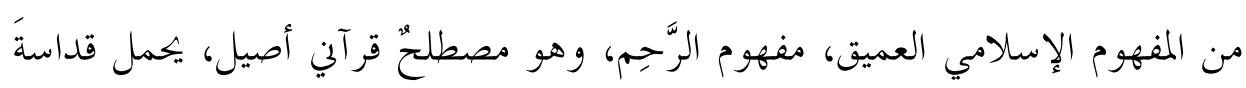

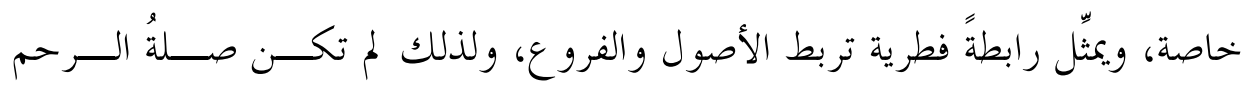
مسؤولية اجتماعية فحسب، بل هي عمل تعبدي. 


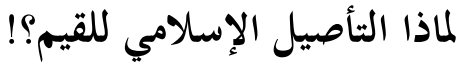

\section{1 البحث عن مرجعية في تحديد القيم:}

ثَمَّة عوامل عديدة تتطلب التأصيل الإسلامي للقيم. ومن أهم هذه العوامل طبيعة

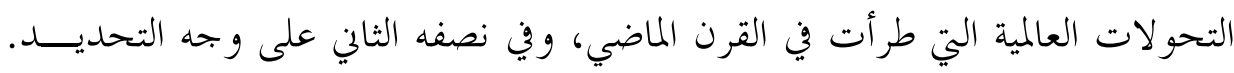

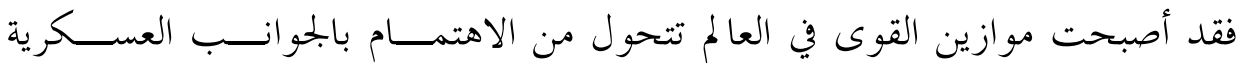
و السياسية والاقتصادية، إلى الجوانب الفكرية والثقافية والاجتماعية، وأخذت المنظمات

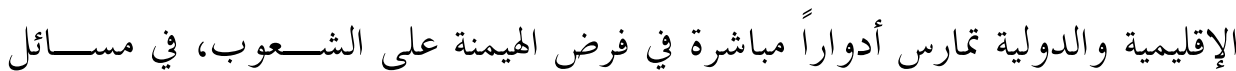

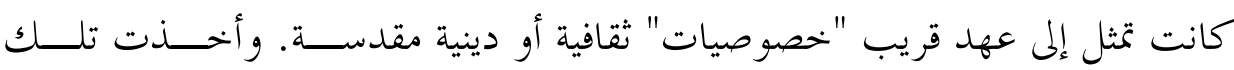

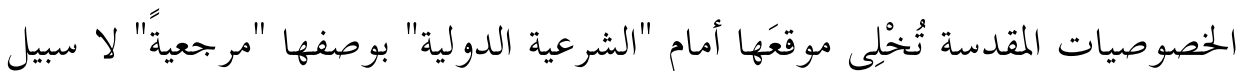

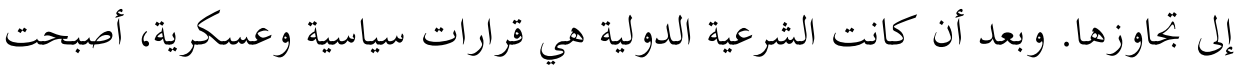

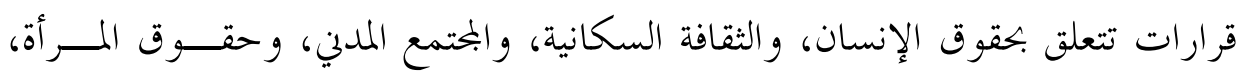
ومفهوم الأسرة، إلخ.

وهذه القرارات تُتَّخذُ عادة في مؤتمرات دولية متخصصة، هُيمن عليها قوى غربية،

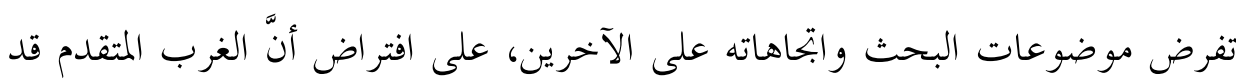

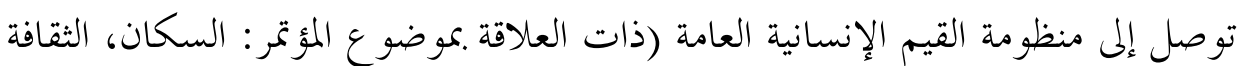

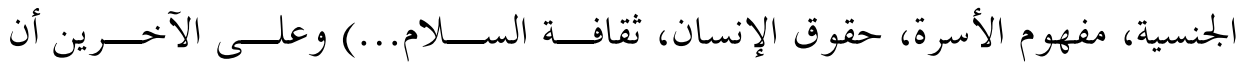

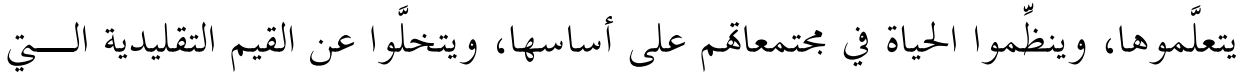
ارتبطت بالتخلف والماضي.

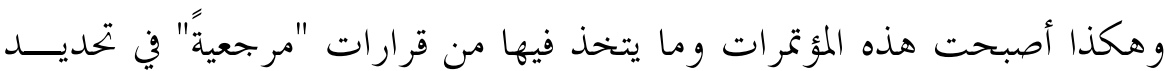
القيم، وأنماط السلوك التي تملك "الشرعية" في كثير من المختمعات العربية والإســلامية.

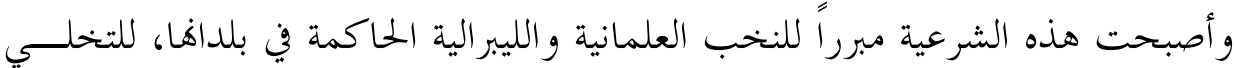

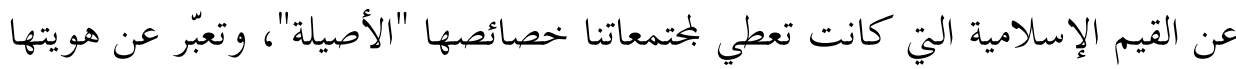




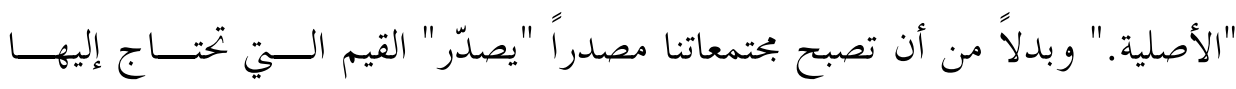
الحضارة البشرية المعاصرة، ويبشر هـا ويدعو إليها، لتحقيق مصالح البشـــرية كافــة،

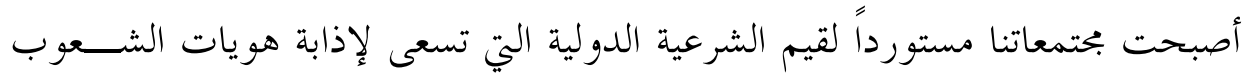

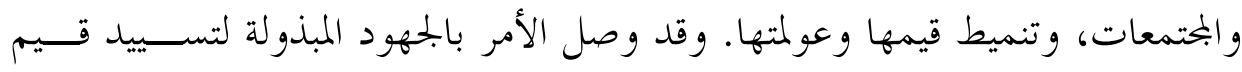

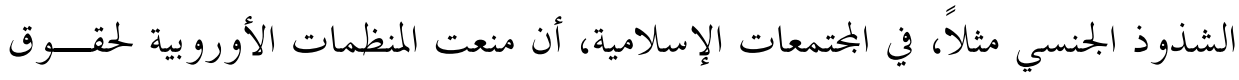

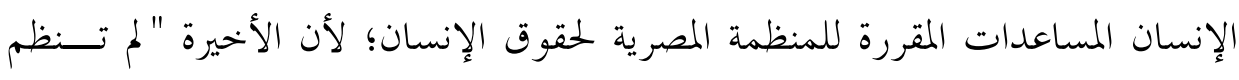

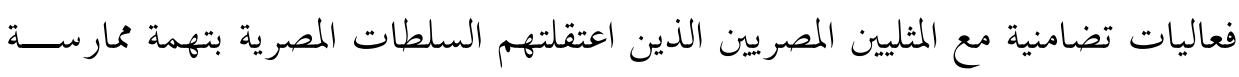

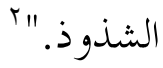

ومن هنا فإِنَّنا نحتاجُ إلى التذكير بالمرجعية الإسلامية للقيم في بحتمعاتنا، بدلاً مــن

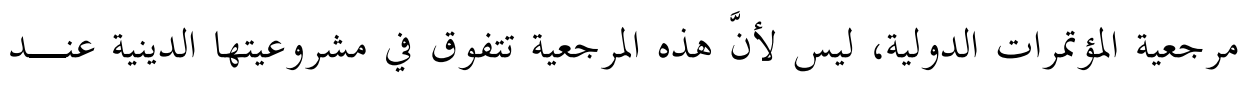

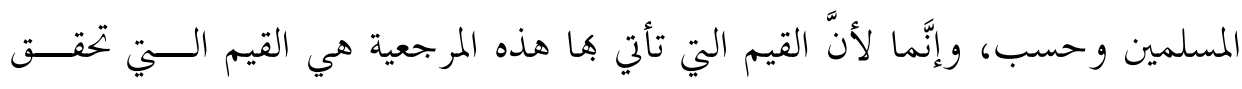

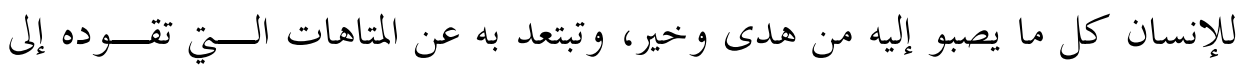

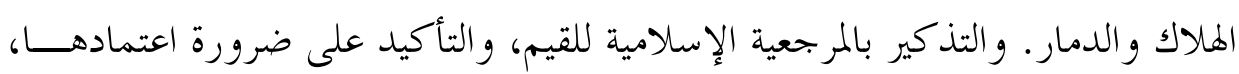
هو ما نودُّ الوصول إليه من تأصيل إسلامي للقيم. والتركية.

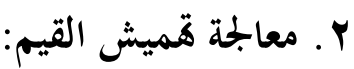

تعَالت الدعواتُ في السنوات الأخيرة إلى ضرورة التكيُّف مع متطلبات العولمـــة،

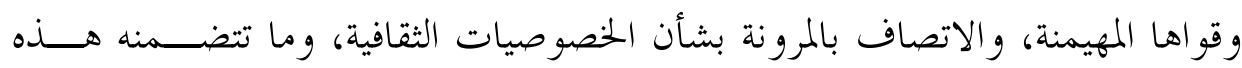

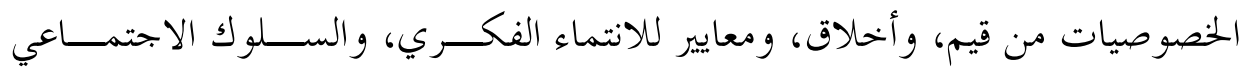
و الاقتصادي. ولا شك في أنَّ قوى العولمة وو سائلها الإعلامية الطاغية قد أدخلت كثيراً من قيمها إلى كل بيت، وأسهمت في "تنميط القيم" في مختلف بحالات الحياة الفرديـــة

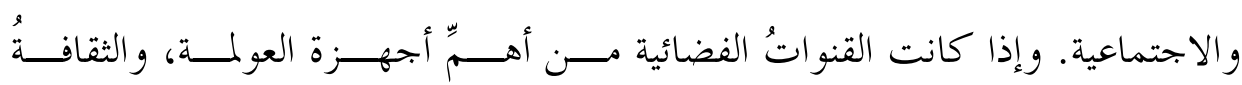


الاستهلاكية من أهمّ المظاهر المرتبطة باقتصاد العولمة، فإنَّ الإسر اف الملحوظ في أفــام

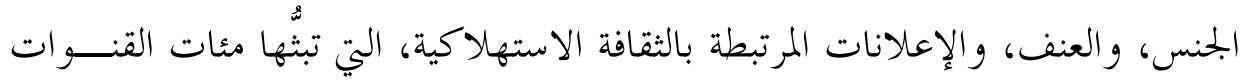

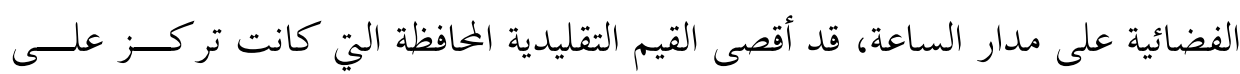

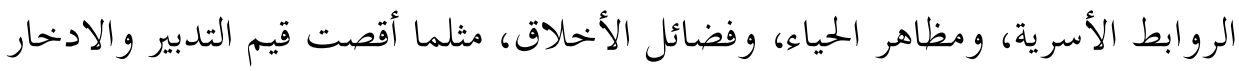
و التكافل ومتعة الشعور بالتميُّز والاستقلال. التعلل بالعولمة إذن أتاح البحال لإحلال "قيم العولمة" مكان "القيم التقليدية"، بحجة

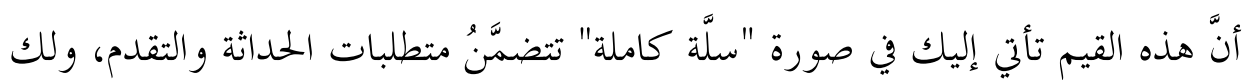

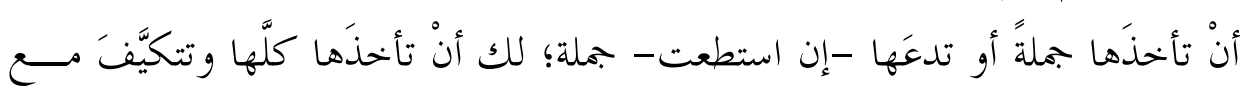

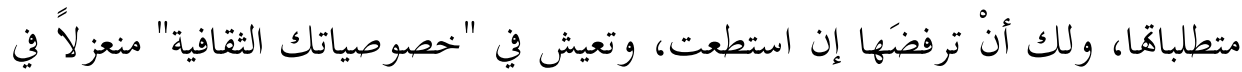

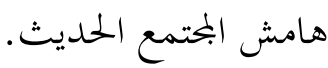

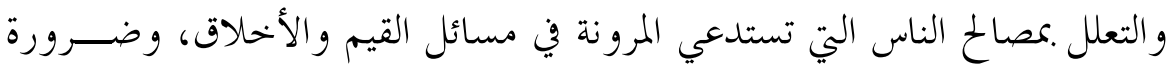

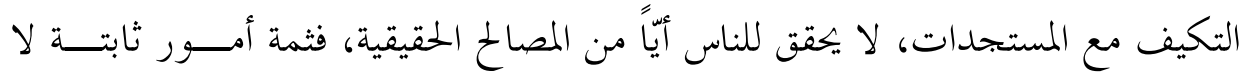

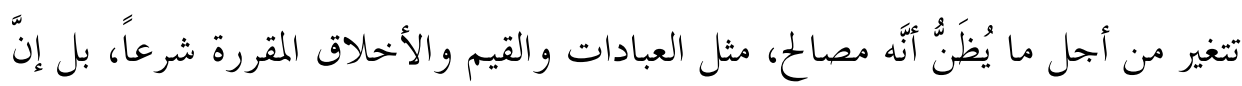

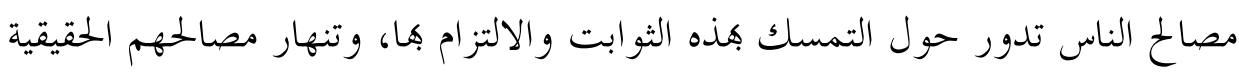

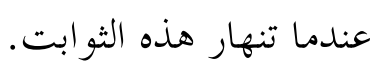

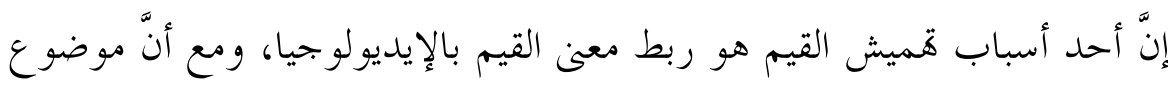

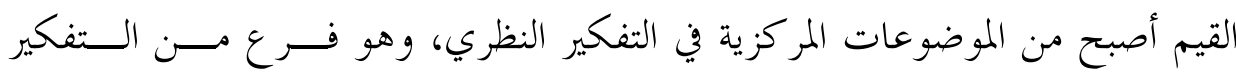

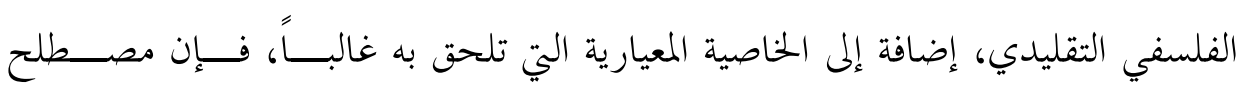

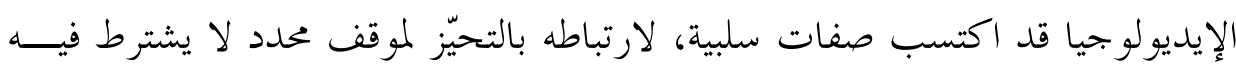

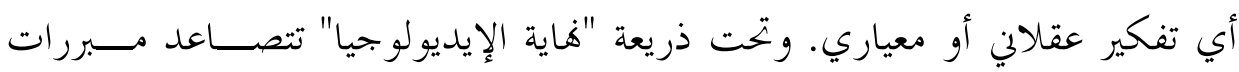
دعوى قمميش القيم! 


\section{r. - معالجة فكرة نسبيّة القيم:}

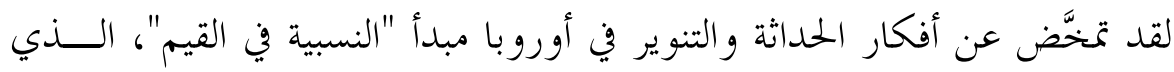

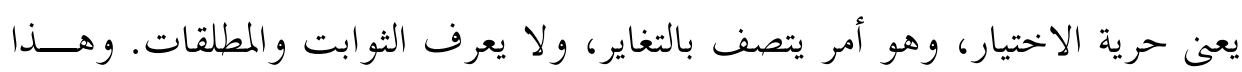

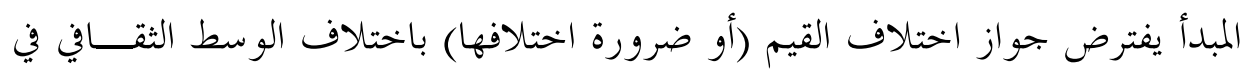

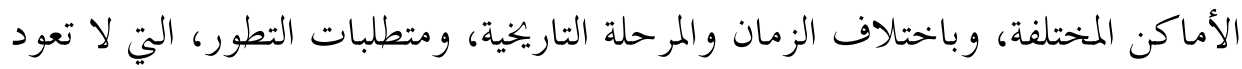

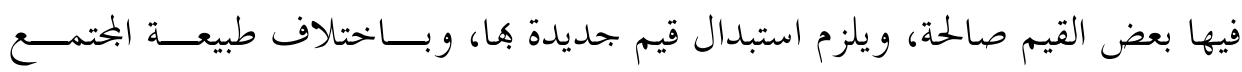

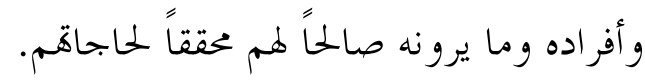

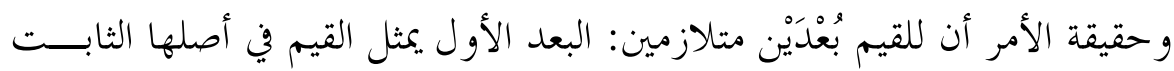

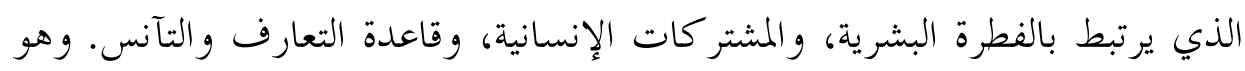

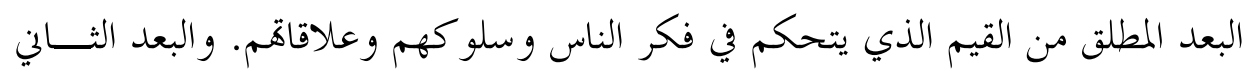

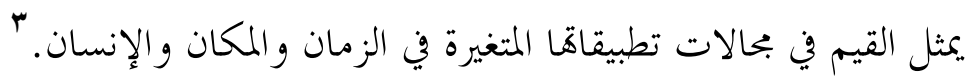

والعلاقة بين البعدين تشبه علاقة المادة ذات التركيب المحدد الثابت، مـــع الوعـــاء

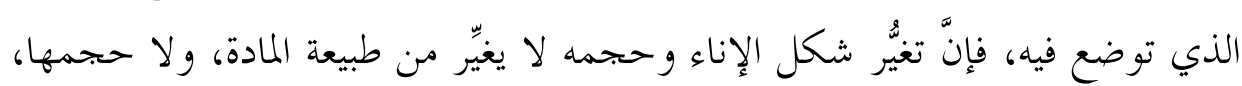

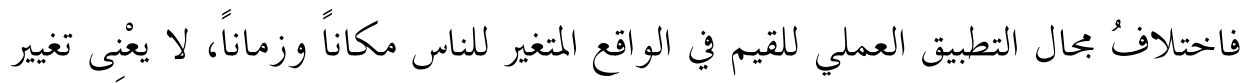

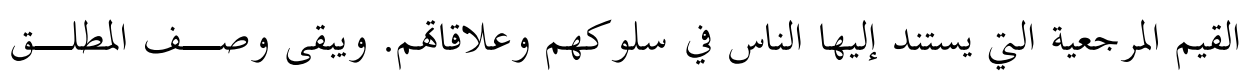
و الثابت للقيم عند تنْــــــلها على الو اقع النسبي المتغير.

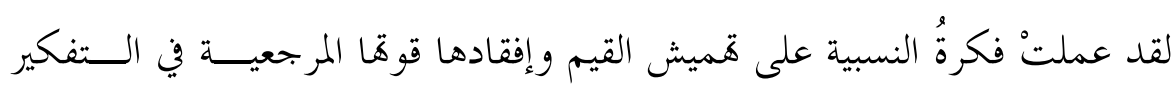

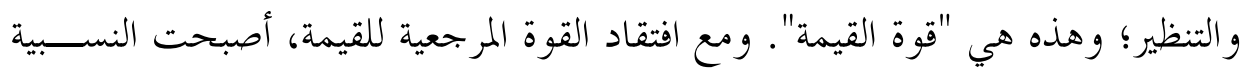
سلطة قهرية تبرر التحلل من أية معايير؛ فأصبحت هذه السلطة تعبيراً عن "قيمة القوة".

† ب إسماعيل، سيف الدين عبد الفتاح. مدخل القيم، سلسلة مشروع العلاقات الدولية في الإسلام، القاهرة: المعهد

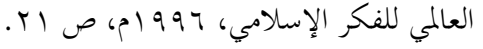


ويسهُمُ التمييز بين قيم الغايات وقيم الوسائل في فهم مسألة النسبية في القيم؛ فقيمُ

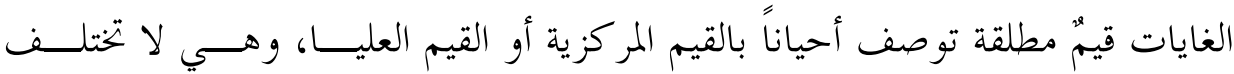

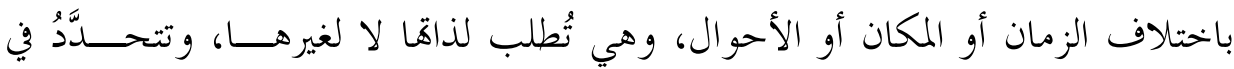
الدراسات الفلسفية بمثلث القيم العليا: الخير والجمال والحق. و وتتحدد في الدراســـات الدينية حسب توجهات الفرق الكلامية بــ: التوحيد والنبوة و المعاد. وتتحدد في بعض ولم

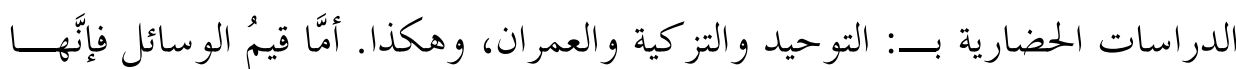

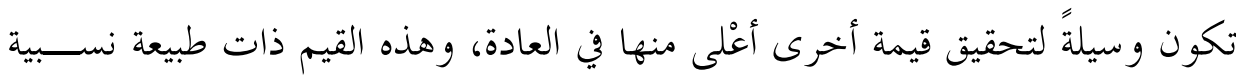

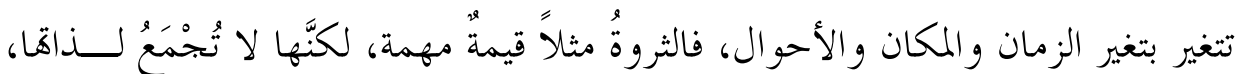

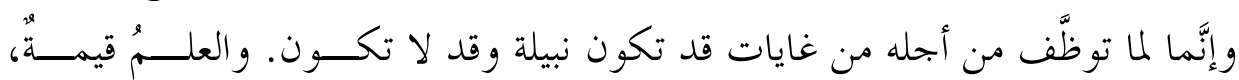
و اكتسابه لا يكون لذاته، وإنَّما يُكتسب لغن لغايات أخرى،، وهكذا.

\section{ع. معالجة ازدواجية المعايير القيمية:}

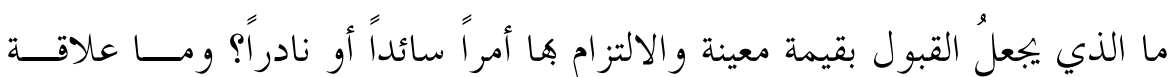

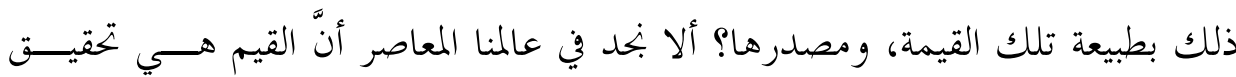
المصالح الخاصة بفرد أو فئة أو بحتمع، دون النظر إلى انعكاسات ذلك على الآخجـرين؟

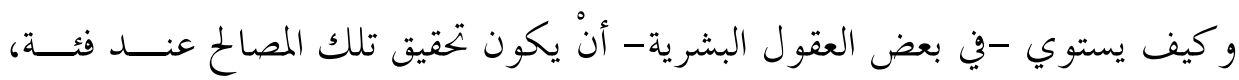

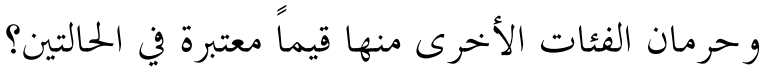
من المعايير الأساسية في تحديد مفهوم القيم، وما يرتبط بها من معــايير أخلاقيـــة،

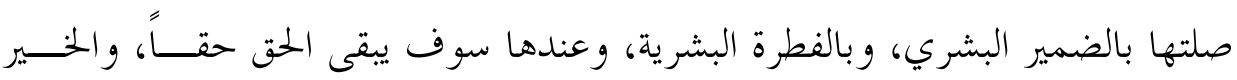

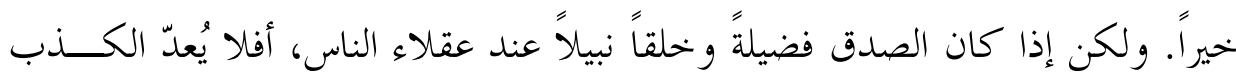

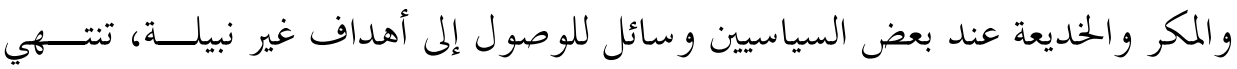

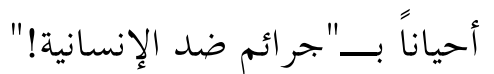


و ننقل هنا نصاً للمفكر الأمريكي المعارض "ناعوم تشومسكي" يقول فيــه: "في

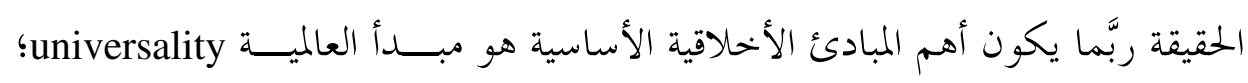

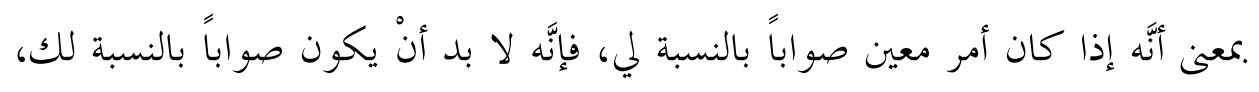

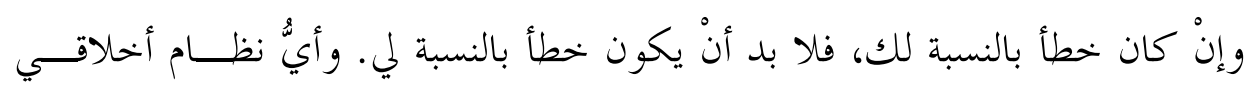

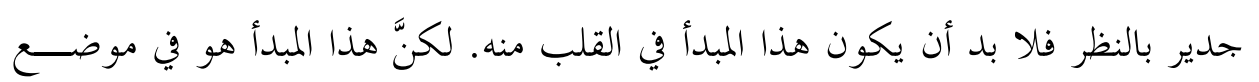

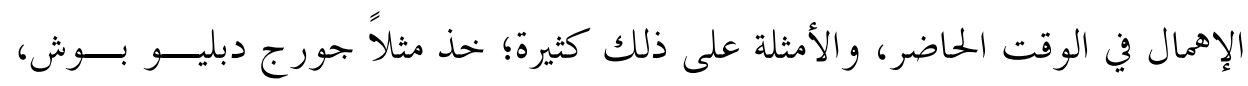

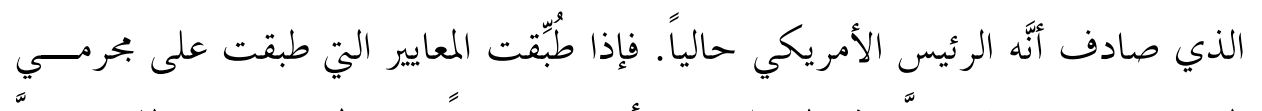

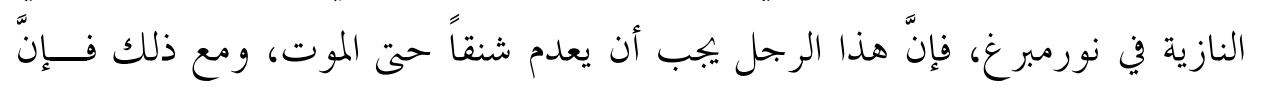

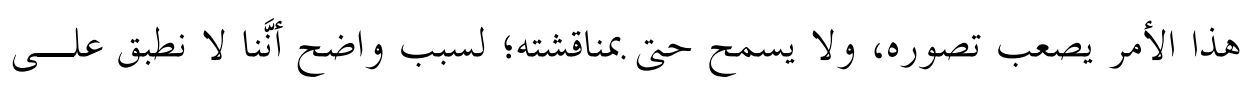

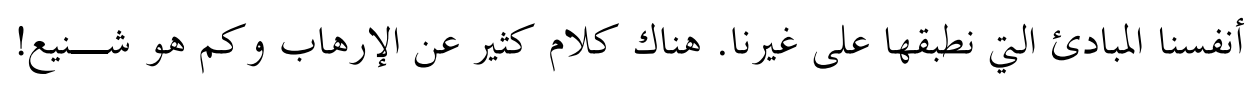

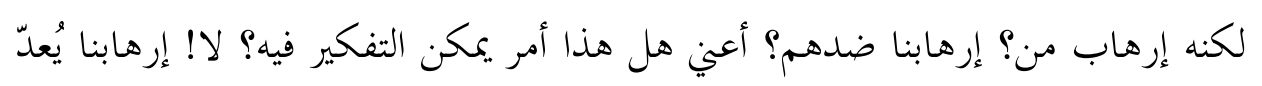

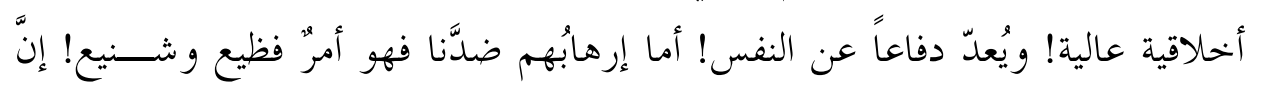

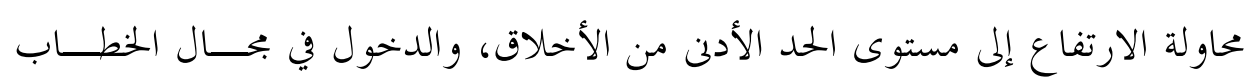

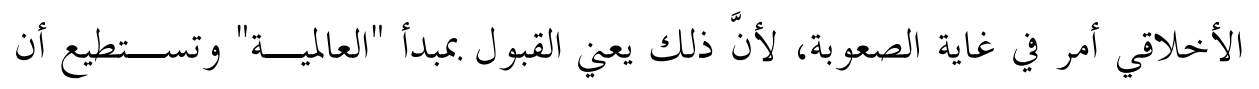
تحرب بنفسك إلى أيٍّ حدِّ يمكن القبول بذلك، على المستوى الشخصي أو في الحيــاة

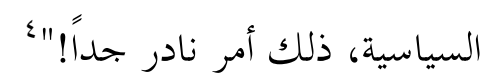

خاتمة:

مصطلحُ التأصيل الإسلامي واحدُّ من التعبيرات العديدة الممثلّة لجهود الإصــلاح الحضاري في المحتمعات الإسلامية، حين تستند هذه الجههود إلى المرجعيـــة الإســلامية، و تسعى لصياغة خطاب إسلامي معاصر، يؤمن بصلاحية الإسلام، ويتعامل مع الواقــع

${ }^{4}$ Chomsky, Noam. Arts and Opinion Vol.6, No. 6. 2007 Interviewd by Babriel Nattew Schivone. 
و مستجداته وقضاياه المعاصرة، ويقدم حلو لاً حقيقة وإبداعية لمشــكلاته، ويســهم في تمكين الأمة من النهوض الحضاري وأداء دورها في بناء حضارة إنسانية راشدة.

و ونقترح في هذا المقام معادلةً معرفية للتأصيل الإسلامي، تقوم على تفاعل العقــل المسلم مع مكونين أساسيين من مصادر المعرفة؛ أولمما: معطيات المرجعية الإســلامية المتمثلة في القرآن الكريم، والسنة النبوية الشريفة، وتراث العلماء المسلمين عبر التاريخ، وثانيهما: إبحازات العلماء و المفكرين من الشعوب والثقافات و الحضارات الأخسـرى،

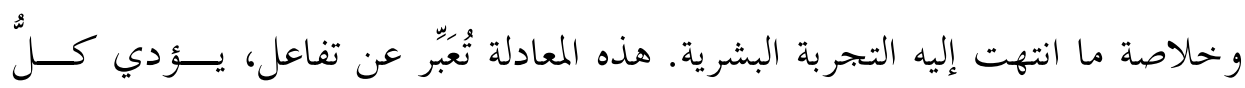

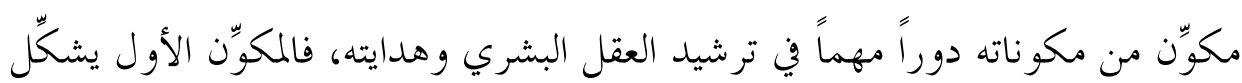

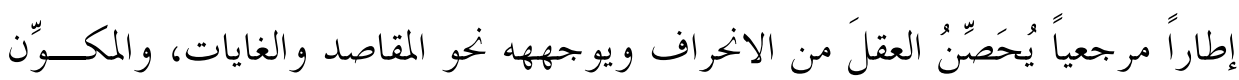

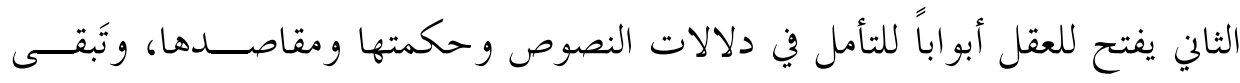
معطياتُ كل من المكوِّيَنْ في تفاعل مستمر في العقل المسلم، بصورة تعين هذا العقـل على استمرار الترقي في الاكتشاف والإبداع. وليس من السهل أن نتصوَرَ هذا الفهمَ للتأصيل الإسلامي في مستوى واحد، فهو

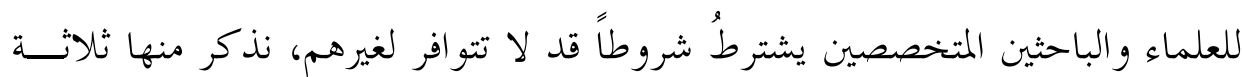

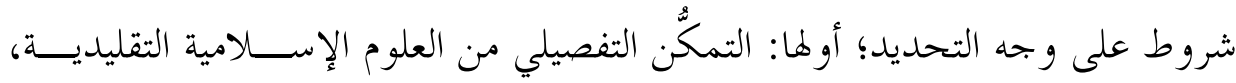
وثانيها التمكن التفصيلي من العلوم الحديثة ذات العلاقة، وثالثها القدرة المتميزة علــى الاستيعاب والتجاوز؛ لإبداع رؤية متطورة متجددة. بينما يكفي لفئات أخرى الإلمام

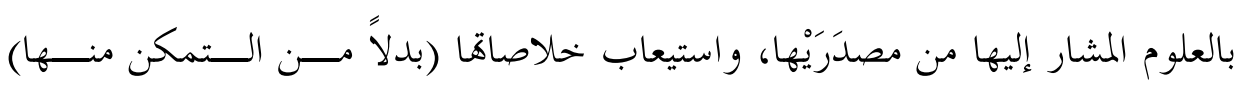
و القدرة على الإدراك الإجمالي لهذه الخلاصات، وفهم صــلتها بالقضـــايا المعاصـــرة، و استحضارها في بناء رؤية الإنسان للأمور وسلو كه في الحياة العملية. 
إنَّ التأصيل الإسلامي للقيم يتطلب جهوداً متصلة من العلماء و المفكرين و الباحثين

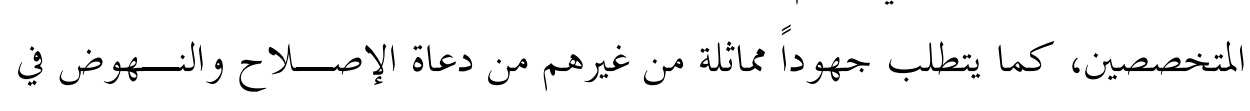

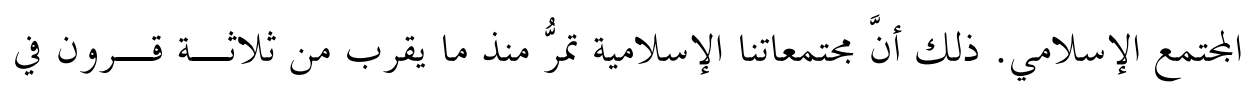

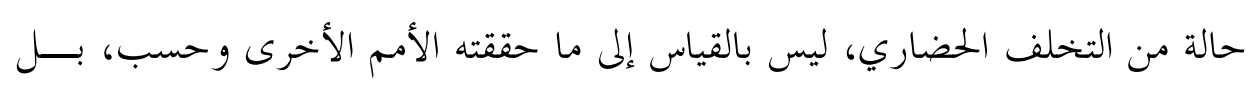

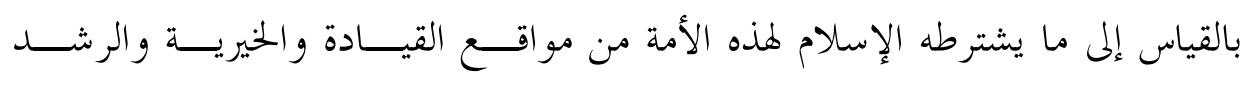

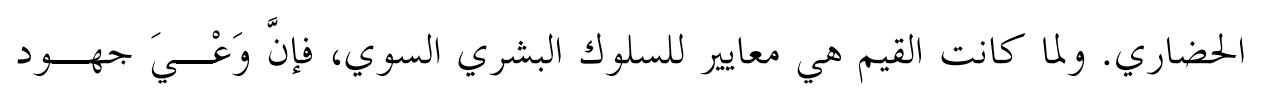
الإصلاح على مركزية القيم في ضبط السلوك وتوجيهه وترشيده أمرٌ على غاية الأهمية.

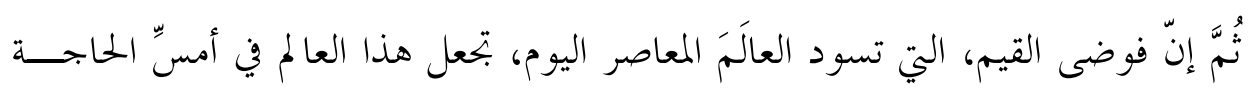
إلى إسهام الإنسان المسلم في تقديم رؤيته؛ لإعادة بناء الشخصية، وإعادة بناء العالم. ولكن هل من سبيل إلى أنْ يَسمعَ العالَمُ صوتَ الإنسان المسلم، عبر رؤيته بلمتمع

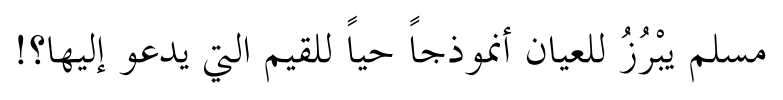

